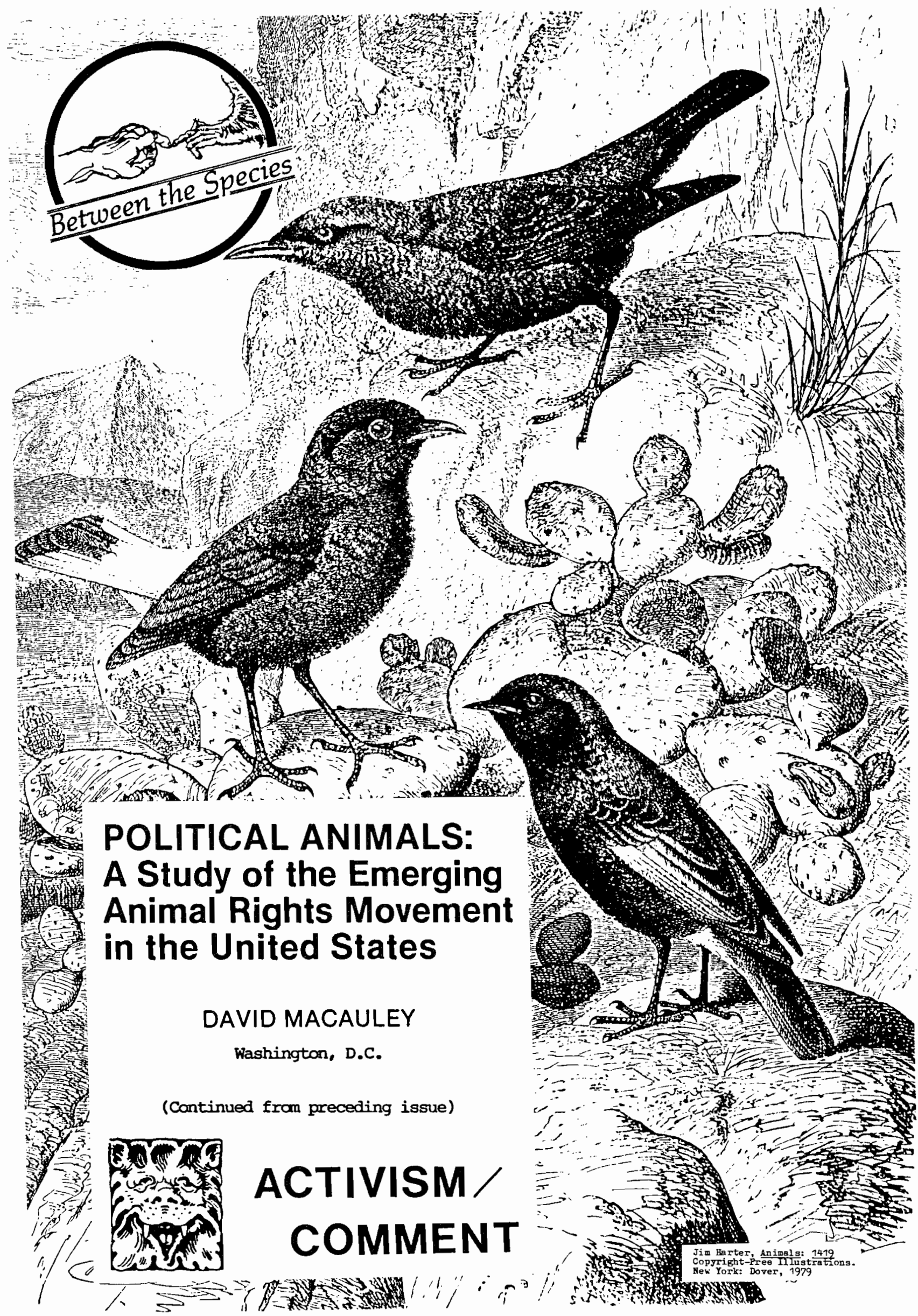




\section{No Room, Save in the Heart}

Poetry and Prose

On Reverence for Life-

by

Ann Cottrell Free

(Author-editor, Animals, Nature and Albert Schweitzer)

$\$ 6.95$ postpaid

The Flying Fox Press

Inquire for quantity rates Washington, D.C. 20016
Animals have entered the political realm more directly as AR groups have formed to. initiate legislation on their behalf, change existing laws through the courts and lobby, support or target selected politicians. Thus a third category of groups, the political-legislative-legal, have the potential to introduce significant changes within the system and to broaden the ordinary understandings of justice to encompass non-humans. While these groups are generally motivated by ideological concerns, they tend to be traditional in approach, non-membership or limited in membership, and oriented toward professional activities and conduct.

The political, legislative and legal organizations perhaps can be best understood in terms of when they came into being. Two of them, the Committee for Humane Legislation (CHL) and the Society for Animal Protective Legislation (SAPL), were founded in 1971 and 1955 respectively, much earlier than other groups which now work in this field. Hence, these groups helped to enact BETWEEN THE SPECIES many of the early protection laws and, along with environmental lobby groups, fought to establish political channels currently used by a variety of organizations. It may be fairly said that CHL and SAPL originated as political extensions of the animal welfare movement, devoting much of their time to securing legislation on issues concerning the living conditions of farm animals, the care of companion animals and the plight of endangered species. In this regard, their programs have tended to be conservative and

regulatory in nature. Four organizations formed more recently, on the other hand, are products of and participants in the animal rights movement and include Animal Political Action Committee (ANPAC), Animals in Politics (AIP), National Alliance for Animal Legislation (NAAL or The Alliance) and Animal Legal Defence Fund (ALDF). With the exception of ALDF, which began in 1979 as Attorneys for Animal Rights, these groups were formed in the years 1982 and 1983.

SAPL, it seems, has been very influential in the efforts to secure animal protection legislation. Since 1955 when only two federal laws existed (the 1906 "28-hour law" regulating the transportation of livestock by rail and the 1948 law which authorized U.S. Customs officials to prosecute shippers of animals when they failed to maintain specified standards), SAPL has helped to enact fourteen federal laws. Among these are:

- The Humane Slaughter Act in 1958 requiring packers selling meat to the government to provide either anesthetization or an electrical or mechanical 
stun to all animals prior to slaughter, except ones used for kosher meat.

- The Wild Horses Act in 1959 which prohibited both the poisoning of water holes where burros and wild horses drink and the use of aircraft to gather horses for sale to slaughterhouses.

- The Endangered Species Act in 1969 and its strengthening in 1973.

- The Marine Mammal Protection Act in 1972 which prohibits, among other acts, the killing, capturing or harassing of any marine animal without a permit.

The most important piece of legislation which SAPL and other organizations worked to pass, though, is what came to be known as the Animal Welfare Act. A product of a number of acts and extensions from 1966 to 1976 and many years of intensive lobbying, this law governs a variety of cases involving animals. The Animal Welfare Act as amended (7 U.S.C. §§ 2131-2156) in Section 1 (b) is designed "(1) to insure that animals intended for use in research facilities or for exhibition purposes or for pets are provided humane care and treatment; (2) to assure the humane treatment of animals during transportation; and (3) to protect the owners of animals from the theft of their animals by preventing the sale or use of animals which have been stolen." 82

The passage of the bill exhibited the classic features of the political process: the subtle interplay of conflict and consensus which culminates at length in legislative change. At various points, versions of the bill were attacked by the National Society for Medical Research as an effort to eliminate the supply of animals to laboratories and opposed by the Department of Health, Education and Welfare (now Dept. of Health and Human Services). The public also became a factor in its passage when, in February 1966, Life magazine printed a story and a collection of photographs showing the abuse of dogs by an animal dealer. Life received more mail on the article than any other in its

history and Congress received more letters on the pending bills than it did on civil rights matters or Vietnam. This publicity subsequently caused opponents of the bill to modify their positions. Numerous other animal protection groups and humane societies were also involved in the process, combatting the powerful lobbies and influential testimony of medical and scientific research organizations.

In fighting for the passage of legislation, SAPL relies primarily on informational resources: circulating letters, periodicals and animal or scientific publications. They prepare reports for members of Congress and encourage persons on their mailing list to write to government officials, Congresspersons and the media. Chairwoman Christine Stevens states that "In our experience moderate, fully researched, aggressively and indefatigably pursued legislation is the most effective means of helping animals." 83 The organization appears to be cautious of many groups that are more radical in their approaches, feeling that a number of serious defeats have resulted from "frightening animal users into a state of powerful combativeness." 84 SAPL also makes clear 
that it is not an anti-vivisectionist organization, although it believes that it is generally perceived as such. "There isn't even one anti-vivisectionist in the entire Congress," points out Christine Stevens. "But there are many who are concerned about inflicting useless suffering on animals," she adds. 85

The Committee for Humane Legislation is an organization similar in purpose to SAPL. It is also like many of the more recently formed legislative and political organizations working for animal protection because it was created to circumvent the restrictions placed on groups with tax-exempt status that are prevented from engaging in any substantial lobbying activity. Strictly speaking, $\mathrm{CHL}$ is therefore an independent entity; however, it is de facto the political arm of the large, national organization, Friends of Animals (FOA). Located in Washington, DC, the lobbying group evolved through the efforts of Alice Herrington who began FOA, Cleveland Amory who founded and presides over the Fund for Animals, and environmentalist Lewis Regenstein. CHL has worked for legislation in a manner akin to SAPL. Regenstein, for example, played an instrumental role in the passage of the Marine Mammal Protection Act by attacking Senator Ernest Hollings, then chairman of the Subcommittee on Oceans and Atmosphere, for Succumbing to interest group pressure from furriers, and working to prevent the adoption of weakening amendments.

ANPAC and The Alliance are separate organizations with distinctly different strategies, but they are under the direction of the same individuals. ANPAC is mainly a political organization in that its function is to help elect Congresspersons who support animal protection legislation. The Alliance, on the other hand, is more of a legislative group because its purpose is to organize a new national network to lobby for bills and laws at the federal level. In general, AR organizations do not have a great amount of experience in lobbying and mainstream political activities, but these two groups along with Animals in Politics are beginning to ameliorate this condition.

ANPAC, like other political action committees (Pacs) plans to raise money to contribute to the campaigns of candidates who are responsive to their concerns and to oppose those who are not. As former director Connie Kagan says, "ANPAC is neither Democratic nor Republican; neither liberal nor conservative. But it is strongly on behalf of animals." 86 In recent years, the organization has published a voter's guide that indicates each Congressional candidate's position on and past action regarding animal issues. The mood among many individuals in the movement has been optimistic about this organization, for Doris Primack of Animals in Politics has remarked that "ANPAC is the current answer to transforming what is now a diffused potential into concrete support where it counts: the Congress," and George Cave of TSU has asserted that "with the creation of ANPAC a new and vital stage in the animal rights movement has been reached." 87 ANPAC, however, faces considerable obstacles in the form of larger, more wealthy Pacs which protect the interests of agribusiness and the vivisection industry.

As previously mentioned, The National Alliance for Animal Legislation is a relatively new Organization whose purpose is to develop a nation-wide network 
of grass-roots lobbyists to support federal animal protective legislation. It's activities have centered on three areas: lobbying on Capitol Hill, circulating co-sponsor lists and publishing a Legislative Summary Chart. The Alliance also brings together representatives from many animal organizations to train them in lobbying techniques in workshops throughout the country and holds a large conference in Washington, DC each year. To date, the Alliance's biggest contribution has been educational and informational in nature. Its bi-weekly Legislative Summary Chart provides information on the status of current bills before Congress and indicates the organization's position on the bill in question. In terms of funding, The Alliance and its political counterpart, ANPAC, have different sources: whereas ANPAC must turn to donations and fund-raising activity, The Alliance relies in large part on support from other AR organizations.

Animals in Politics is perhaps the paradigmatic organization among the political and legislative AR groups. AIP's brief history, in fact, is an interesting one which merits some attention because, to an extent, it mirrors the vicissitudes of the movement. AIP began as one of the four task forces created along with a board under the name of Animal Rights Mobilization (ARM) at a meeting of about $\mathbf{2 0 0}$ members from various AR and AW groups in October, 1981. Two of the task forces which focused on media and bloodsports subsequently failed while a third, the Primate Center task force, detached from ARM under the direction of activist Richard Morgan and incorporated itself as Mobilization For Animals (now defunct). Two of the three coordinators of the Animals in Politics task force left and Doris Primack, who is still coordinator, assumed full control. After it became apparent in the summer of 1982 that ARM was not going to be a strong voice for animals, Primack eschewed compomise and made AIP into an independent group which worked for the

passage of legislation. Then in early 1984 , AIP indicated that it was planning to merge with The Alliance because, according to Primack, "we do not believe in duplication of efforts and since this type of work should be headquartered in Washington." 88 Hence AIP has gone from an ad hoc existence to independence and finally to unification with a similar group.

AIP's structure, tactics and goals are especially representative of this category of AR organization. AIP has classified itself as an abolitionist rights group which approves of illegal and destructive tactics when necessary. It does not have any members except for a mailing list; there are no set fees; and structure is completely open, without designated officers because they "believe in a democratic institutional style, short of it being disruptive." 89 AIP also views its role as one of raising political awareness. Writes coordinator Doris Primack in letter correspondence:

In the relatively short time of our existence we have found the average AR proponent to be woefully ignorant of legislation, the legislative processes, and the impact of politics on legislation, not even knowing the names of their legislators. In short, we find them long on enthusiasm but short on knowledge. We feel very strongly that this situation must be remedied if we are to gain influence where it counts, and we make 
education in this direction one of our main goals. We believe that demonstrations and direct action are necessary, but they are only half the job and must be followed up with direct pressure on members of Congress by their constituents. 90

To secure these goals, AIP has used a number of additional approaches, including the dissemination of "action alerts" on legislation, participation in and publicizing of demonstrations and a project involving the compilation of data on the "pro- or anti-animal position" of members of Congress.

A final organization within the category of the political-legislative-legal groups is the Animal Legal Defense Fund. ALDF is a national non-profit association of attorneys and law students who share a concern for the the treatment of animals, and it is as vital. to the movement as the strictly legislative and political organizations. With approximately 200 members, ALDF has chapters in five cities and is active in a number of legal areas. They have, for example, brought legal action against the U.S. Navy to halt the killings of burros at China Lake, California; helped to prevent the death of Sido, a dog whose deceased owner willed him to die; and filed suit against a large airline company in connection with the death of an animal in the cargo section of a plane. In addition, ALDF attorneys have assisted in drafting an important amendment to the California Endangered Species Act and prepared an extensive report on animal pain. Each of the chapters has been active in its geographical region as well. ALDF (DC) has established a series of speaking engagements at law schools; ALDF (Los Angeles) has investigated laboratory research in California universities; and lawyers in ALDF (Boston) have brought suit against a veal producer and opposed the face branding of cattle.

While the cumulative effect of ALDF's efforts in terms of the number of animals it has saved is not enormous, its impact on the legal profession has been much greater and will likely grow as more legal precedents are established. ALDF's biggest barrier, and one of the movement's main obstacles, has been the rather rigid or fixed legal status of animals. However, it is against these barriers - which attorney Steven Wise distinguishes as "property" and "standing" that ALDF has begun to make some progress. Lawyers, for example, are starting to assert the "rights" of animals directly rather than through their legal "owners". In 1981, for example, Joyce Tischler filed a malpractice suit against a veterinarian who had wrongfully injured a dog, and one of the plaintiffs in the case was the animal, named Sterling Berg.

Other cases involving animal mistreatment are being considered as well. In October 1983, The Animal Rights Law Reporter (now defunct) took note that a California court has awarded a childless couple joint custody of a dog following their divorce proceedings. The judge concluded that the dog was, in effect a "child substitute" and thus was to be treated under the state's child custody laws. Neither individual can take the dog out of the state without securing the written permission of the other person. Even where the claims of animals cannot be asserted directly, lawyers are helping to establish the rights of 
organizations and individuals to sue in their behalf, in order to give the plaintiffs legal standing. This step is undoubtedly a necessary one in the slow process of changing institutions and attitudes. Signs of progress are also evident in numerous US law schools, where courses are being offered on animal rights. ALDF's first conference in April 1983 was a self-proclaimed "smashing success" because it brought together experienced individuals from the movement to discuss the potential for litigation in different areas of focus. 91 In the future, ALDF plans to pursue at least three objectives: to establish programs for obtaining a steady source of funds, to expand the network of attorneys to reach every major metropolitan area and to index and expand their pleadings file.

\section{D: Groups United by Strategy}

Activity or strategy is the fourth genre of AR groups and it can be subdivided into "informational" organizations and "direct action" organizations. Since education and information are essential to creating change, the former groups have an important role in the movement. They provide the potential for coalitions and networking, and a forum for discussion. While most AR groups collect, distribute and share information in so far as it is necessary to achieve certain political ends, several groups specialize in this field, acting almost as a clearinghouse for ideas. Direct action groups, on the other hand, are less prevalent but just as vital to the movement. For many years, they were largely a foreign phenomenon, but are now very much part of the US movement. Direct BETWEEN THE SPECIES action groups share a number of characteristics to a greater or lesser degree: they are generally smaller, more secretive and decentralized in organizational structure than other groups; they are often self-funding and not extremely interactive with other organizations; and they frequently employ illegal and controversial tactics. Finally, they tend to be the most ideological, abolitionist groups in the movement since they are not content to wait for gradual change while animals suffer.

One of the most influential organizations in the informational field is The Animals' Agenda, whose income is financed through the Animal Rights Network, Inc. and its own subscriptions. Their only activity is to publish a magazine 10 times each year. In this endeavor, which began in 1979, they have been extremely successful and now distribute 30,000 copies. The Animals' Agenda prints articles on a host of topics ranging from kangaroo slaughter, dissection and zoos to roadkills, genetic engineering and "eggribusiness". The magazine notes that it tries "to reach people at all levels of consciousness and commitment to inspire a deep regard for, and activism of, animals and nature." 92 Its editors and contributers are individuals with much experience in the movement.

Another organization which primarily collects and disseminates information on animal issues is Argus Archives. Argus, the 100-eyed creature of Greek legend, is an appropriate appellation for the group, which is a guardian of a wealth of information on animal subjects. Located in New York City, it was founded and is still presided over by Dr. Dallas Pratt, who has written two 
important books entitled Painful Experiments on Animals and Alternatives to Pain in Experiments on Animals and worked for animal protection since 1969. Argus Archives maintains independence from specific AR groups and does not take stances on issues in the movement because Pratt feels that it would be inappropriate in much the same way that it would be inappropriate for a library to make a judgement of issues of public interest."93

Nevertheless, its resources are open to the media, writers and the public, and such access has aided the AR movement. Argus Archives also publishes reports and books and conducts film presentations on animal issues several times a year. The use of films and videotapes has, in fact, become an increasingly viable tool used in outreach by AR organizations. Films and videotapes depicting animal abuse seem particularly effective for several reasons. First, like poetry, they vivify the facts in a way that statistics, pamphlets and even demonstrations cannot. Secondly, they reveal in a graphic manner the institutional nature of animal suffering and death on modern farms and in laboratories of which the public is often ignorant. Finally films and videotapes which cater to all ages and groups arouse emotions and spur people to action.

Two additional groups, United Action for Animals (UAA) and Human/Animal Liberation Front (HALF), provide important informational services to the movement as well. Both of these groups conduct research on animal experimentation and make it available to individuals and small, grass-roots groups throughout the country who may not have access to this information or the time or money to obtain it. Along with The Animals' Agenda, several other independent publications regularly discuss animal liberation within their pages, including The Animals' Voice and Between The Species (each published in California) and Lomakatsi (published in Washington, DC).

Among direct action groups, one of the most successful has been the Animal Liberation Front (ALF). The ALF is particularly representative of this category of AR "organizations" because (a) it is very decentralized in nature with no real structure or membership beyond that of individuals who decide to act directly on behalf of animals; (b) its income is erratic and generally financed by the activists who make it up; and (c) its concerns are international in scope. Remarks by ALF activists in a recent interview published in Lomakatsi give a sense about this "non-group":

We are not members of the ALF; in fact, the ALF does not have one single member. We are ALF activists by virtue of the fact that we carry out actions, whether on an occasional or frequent basis. As soon as superglue has been squirted into a fur shop lock, the person involved becomes an activist. There is no membership, no hierarchy, no leaders and no centralized policy-making ... you quite simply take action on your own, with friends you can trust. The ALF isn't for heroes, egoists, or those who just want to belong to an exclusive club. The ALF is for those of us who no longer have faith in parliament or leaders, those of us who care enough to know when to keep quiet and when to act. 94 
The origin of the ALF can be traced to Great Britain and to 1973 when a number of members from the Hunt Saboteurs Association felt it was necessary to breach the law in order to fight effectively against bloodsports. These individuals began to vandalize hunt vehicles and eventually formed an organization called the Band of Mercy, a name that honored a nineteenth century direct action youth group of the Royal SPCA which damaged the guns of hunters. Eventually, the Band of Mercy extended its sphere of concerns from bloodsports to all animal abuse, sabotaging breeding centers and setting fires at the construction site of a laboratory which was to be used for animal experiments. In 1974 two members were arrested and subsequently jailed for three years on criminal charges after a laboratory raid. These incidents generated much media attention and increased the size of the Band so that in June 1976, the group became the Animal Liberation Front.

ALF's philosophy is unabashedly straightforward despite its clandestine modus operandi: "The ALF supports a campaign of all-out direct action," writes one experienced activist. 95 To achieve its goals of saving as many animals as possible and generating attention toward the plight of animals, the ALF has often used destructive tactics against furriers, laboratories and the food industry throughout Europe, Canada, the US and even South Africa. Their actions are illustrative of the nature of the group. In many cities, activists have attacked fur shops, breaking windows and pouring powerful glue into the door locks so that customers cannot enter. Since 1981, the ALF BETWEEN THE SPECIES has been conducting raids on animal premises in Canada and has damaged stores, packing plants and laboratories in Toronto, Vancouver, Ottawa and Montreal. in June 1981 several activists rescued twenty-one mutilated animais during a raid on the Hospital for Sick Children in Toronto. "It was like walking into Frankenstein's room," remarked one person involved in the action. "There were dogs that had been devocalized, a pig covered in burns, and cats with their ears .96 These actions have received a great deal of media attention and provoked a number of scathing editorials like one in the Toronto Star which condemned the experiments on animals as "scientific sadism." 97 More recently ALF groups in Canada have hit the University of Toronto Dentistry School and a lab at Western Ontario University.

In the U.S., ALF activists in hooded garb that conceals their identity have freed research animals in Florida, Washington DC, California, Pennsylvania, Oregon, Maryland, Nevada and Maryland. Direct action campaigners, too, have been especially effective in the United Kingdom and Germany. In Great Britain, the ALF has set fire to commercial trucks at a meat processing plant that resulted in $\$ 100,000$ damage, vandalized a company that produces shark fin and turtle soup and released stink bombs at the Miss Nottingham beauty paegent which was sponsored by a fur company, among many other actions. The ALF was also responsible for $\$ 250,000$ worth of damage to a research laboratory in Munster and the rescue of animals throughout the country. And in Capetown, South Africa it has defaced ivory stores with slogans like "Bloody Ivory" and "Ivory Kills Elephants." 
While it uses more militant action to work toward the goal of ending animal exploitation, the ALF generally takes extreme care to ensure that no harm is caused to either humans or animals. Once their safety is established, rescued animals are released into the wilderness or given homes. In some instances, however, ALF acitivists will, if necessary, humanely kill an animal which is in extreme pain.

The direct action of the ALF is the source of its strength but also a subject of controversy and criticism from two different perspectives: the public and some individuals within the movement. In more militant causes, the support of a large section of the public is often crucial, if not necessary, and this appears to apply to the AR movement as well. The ALF reports that a public opinion poll conducted in August 1983 by NOP Market Research found that thirty-five percent of the people in England approve of animal activists breaking into laboratories and removing animals about to undergo experimentation, while a more recent poll by an AR group in Bristol revealed that more than fifty percent of population supports the actions of the ALF. In the US, The Animals' Agenda poll of its own readers showed that the number who support ALF-type raids surpasses those who do not among AR activists as well. Despite this level of support for direct action, a considerable amount of sentiment against the ALF exists in conservative camps. Referring to the ALF's release of 3,300 mink from farms in Essex and Suffolk, England, the British paper, The Daily Express, has asserted:
It is a hatred of women who wear mink coats which drives them to excess, just as those who sabotage hunts do so not out of love for foxes but out of hatred for fox-hunting people ... The Animal Liberation Front is a people-hating, not an animal loving organization, political and not charitable in its motives, a constituent element not of the loony left but of the nasty left. 98

The criticism from certain factions of the movement, most notably the more moderate welfare groups, is equally strong at times. Commenting on the ALF, Dr. Michael Fox, Scientifc Director of the Humane Society of the United States, has written:

Violence (and indeed the liberation of mink into the countryside is an act of violence against nature) may give cathartic satisfaction and thus seem justified, and seem like a public demonstration of strength. But is is a selfish display of weakness, of anguish and ignorance, which are the underpinnings of moral anarchy rather than satyagraha. 99

The Hunt Saboteurs Association (HSA or "Sabs") is another direct-participation or direct-action British group with similar ends. Formed in 1963, HSA actively opposes all "bloodsports". HSA's tendency, unlike that of the ALF, is to protest within the limits of the law, rather than deliberately planning illegal actions. Their strategies are diverse and clever: they frequently dress as hunters and lead the hunt in the wrong direction, cover the scent of a pursued animal with smelling substances, drive rabbits out of the woods and distract hunters and hounds with horns. 
For these actions, Sabs, who gather in the hundreds at hunting events are often beaten and verbally abused by hunters, assaulted by police and taken to jail or court. Such violent responses to non-violent action, however, elicit public attention and increase the awareness of and opposition to bloodsports. Despite the organization's individual successes which include ruining numerous tournaments, their influence at the institutional or national level has not been as great as they would like it to be. Laments Marley Jones, a hunt saboteur for more than ten years:

When the HSA was formed in 1963, there were 197 fox hunts. Now there are 208. The amount of violence has also increased, as well as the use of the law courts. The only bloodsport to be outlawed in that time has been Badger digging, and that went underground. 100

Looking to the example set by the English, activists in the US have of late started to organize hunt sabotages in a few areas, including a December, 1987 disruption of a big-horn sheep hunt in Southern California.

Briefly and finally, there are two prominent international direct-action groups which fight to protect the lives of marine animals: Greenpeace and the Sea Shepherd Society. Greenpeace is a nongovernmental nine-member international organization which until the recent French scandal used its ship. The Rainbow Warrior, to combat seal hunters and whalers, to create what ex-president of the Greenpeace Foundation Robert Hunter terms "international incidents" and to harass governments whose BEIWEEN THE SPECIES environmental policies are exploitive of animals. Greenpeace's actions are non-violent whereas The Sea Shepherd Society tends to use more aggressive tactics. Greenpeace activists, for example, have dyed the fur of seal pups to make their coats useless to commercial trappers, positioned themselves in rubber boats between whales and Japanese and Russian whaling ships and sailed into Soviet waters to protest international whaling.

The Sea Shepherd Society is an offshoot of Greenpeace. Paul Watson, one of the founders of Greenpeace, formed the Society with his wife after he was dismissed from Greenpeace in 1976 for removing a club from a sealer's hand. Since that time, his mission has been militant and his commitment unwavering. According to Watson's account of his endeavors in Shepherds of the Sea, he is led to direct action because he is "not content to shuffle papers and scribble mere letters of protest."101 Along with the crew of the ship, Watson has shut down numerous whaling vessels, sprayed hundreds of seal pup coats, damaged computers and machinery in a whaling processing plant in Iceland, and raised enough awareness of and opposition to sealing and whaling to stop many hunts.

The most controversial activity of the group, however, has been its assault on private whaling ships. In 1979, for example, the crew of the Sea Shepherd risked their lives to track down and ram the pirate whaler, Sierra. In the process of Watson's assaults, he has been beaten, threatened and arrested but still remains adamant, threatening to sink any Canadian whaling ship: "The first report I get of a fishing boat 
firing at a seal, the ship's going to disappear." Watson's attitude and commitment are indicative of the kind of outlook which is predominant among many activists and which increasingly characterizes the AR movement. In an interview with activist Mary Ann Violin, Watson was candid about his view of animal protection and human obligations:

Sabotage hunts, sabotage the fur industry.

Sabotage laboratories that are experimenting on animals. But as far as being radical ... our group is not radical. The real radicals are the people who are killing off the whales and destroying the oceans. We're a conservation organization - we're the ultimate conservatives ... I think everybody has the responsibility to be a custodian or shepherd to the planet, to give some service to the earth. ... Like the Oglalas say, 'Hoka Hey, Its a good day to die.' Once you are willing to take risks and are not afraid of the possibility of being injured or dying, then you can accomplish anything you want to do. 102

82

Animal Welfare Act, 7 U.S.C. $\$ 2131$ 2156.

83 Letter to David McCauley from Christine Stevens, Executive Secretary, Society for Animal Protective Legislation, 10 January 1984.

84 Ibid.

lbid.
86

Letter to David McCauley from Connie Kagan, Director of ANPAC, 12 January 1984.

87

ANPAC, brochure for distribution, no date.

88

Letter to David McCauley from Doris Primack, Coordinator of Animals in Politics, 19 January 1984.

89

Ibid.

90

lbid.

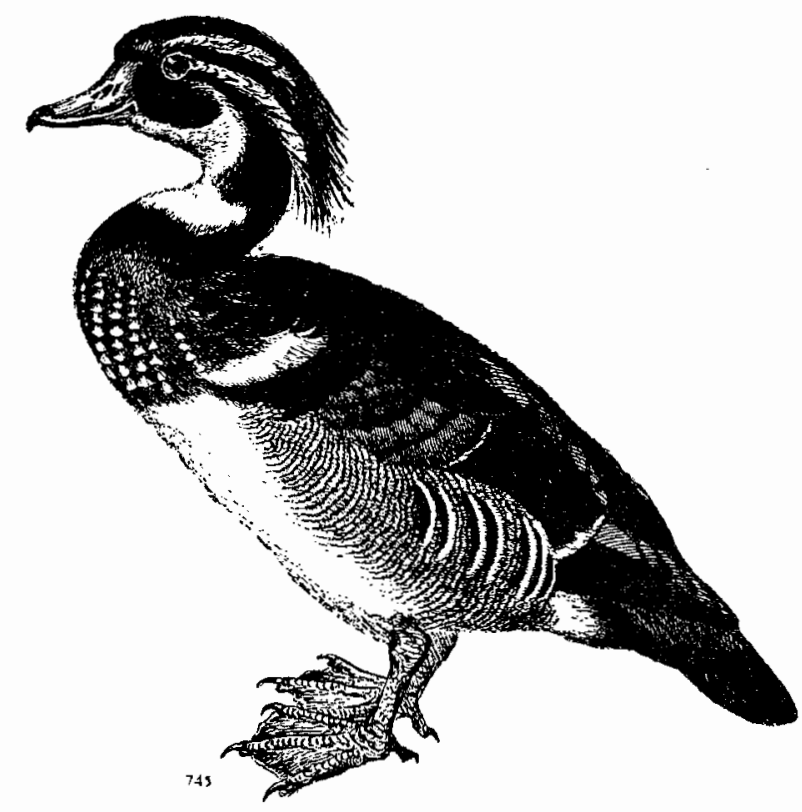

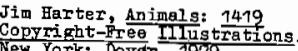


"Attorneys for Animal Rights Newsletter," Fall 1983.

92

The Animals' Agenda, statement of purpose, p. 2 of each issue.

93

The Animals' Agenda 2/3 (May/June, 1982), pp. 13-14.

94

"ALF on Trial," Lomakatsi 1/1 (Spring, 1987).

95

Anonymous response from ALF in Great Britain to questionnaire distributed by David McCauley, November, 1983.

96

Ihe Animals' Agenda $1 / 2$ (Sept./Oct., 1981), p. 5.

97

lbid.

98

The Animals' Agenda 4/1 (Jan./Feb., 1984), p. 28.

99

Ibid.

100

The Animals' Agenda 3/3 (May/June, 1983), p. 5.

${ }^{101}$ Paul Watson, Shepherds of the Sea (Vancouver, BC: Sea Shepherd Conservation Society), p. 3.

102

The Animals' Agenda 2/1 (Jan./Feb., 1982), p. 22.

BETWEEN THE SPECIES

\section{BELUGA \\ Paulette Callen}

white robed

mona lisa smiling

madonnas

of the cold seas

devotees

at play

in the

glacial cathedrals

of the Most High

white mala pearls

dancing on the snowy breast

of the Mother

their songs

what are they to us?

of what value the spinning wheels of prayerful Tibet?

of what value the sacred chants rising from the ashrams of India?

of what value the plainsong from the austere monasteries of Europe?

of what value the smoky meditations of the

North American sweat lodge?

of what value the mighty voice of the

Trappists breaking silence only for song?

the saddhu

the shaman

Cistercians and Cetaceans

have the world's work to do

singing us out of the Darkest Age

let us save the whale

for she may save the world 